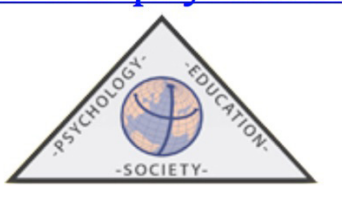

\title{
Attribution of Value, Teaching and Assessment in the Perception of the Performance of Specific Competencies of Undergraduates Studying Social Work
}

\author{
José Juan CARRIÓN MARTÍNEZ, Maria Del Mar FERNÁNDEZ MARTÍNEZ, \\ Antonio LUQUE DE LA ROSA y Carmen María HERNÁNDEZ GARRE
}

\author{
Universidad de Almería
}

(Recibido el 22 de Enero de 2020, Aceptado el 9 de Junio de 2020)

\begin{abstract}
This paper addresses an issue of concern with regards to the teaching of competencies within the context of undergraduate university studies, in this case, in the field of social work. In it, we question if the basic curricular processes of the explicit instructional, teaching and assessment system regarding specific competencies of professional social work are effective in promoting, improving or training in the performance of these specific competencies, or if, on the hand, they are axiological in nature and can better explain the performance of specific competencies by undergraduate students studying social work. A survey method has been followed. Data were analyzed using a two-step multiple lineal regression analysis with bootstrapping based on 5,000 resamples. The results suggest that the subjective assessment of the competencies by undergraduate students of social work could affect the relationship between the perception of teaching and evaluation of competencies and the subjective level of their own competency in them. These results provoke an inescapable reflection on the validity of pedagogical practices for promoting the self-assessed performance of the specific competencies of social work by future professional practitioners, opening the door to a reflection on the ways of influencing the competency performance of the current teaching and evaluation processes in higher education.
\end{abstract}

Keywords: Perception of Competency Performance; Motivational Factors in the Performance of Competencies; Explicit Teaching of Competencies; Explicit Evaluation of Competencies

Atribución de valor, enseñanza y evaluación en la percepción del desempeño de las competencias especificas en estudiantes de grado en trabajo social

RESUMEN: En este trabajo se aborda una cuestión que nos preocupa especialmente dentro del enfoque de enseñanza por competencias presente en los estudios universitarios, en este caso en los de trabajo social. Nos preguntamos si los procesos curriculares básicos del sistema instruccional, enseñanza y evaluación explícitas en el caso del abordaje de las competencias específicas del profesional del trabajo social, están siendo efectivos para promover, mejorar o capacitar en el desempeño de dichas competencias específicas, o si por el contrario son elementos de otra índole, axiológica, los que mejor explican el 
desempeño de las competencias específicas en los estudiantes del grado en trabajo social. Se ha seguido un método de encuesta. Los datos fueron analizados empleando un análisis de regresión lineal de dos pasos con una técnica de bootstrapping de 5,000 remuestreos. Los resultados sugieren que la valoración subjetiva de las competencias por parte de los estudiantes del grado en trabajo social podría afectar a la relación existente entre la percepción de enseñanza y evaluación de las competencias y el nivel subjetivo de propia competencia en las mismas. Estos resultados provocan una ineludible reflexión sobre la validez de las prácticas pedagógicas para promover el desempeño autopercibido de las competencias específicas del trabajo social por los futuros profesionales acreedores de esas capacidades, abriéndose la puerta a una reflexión sobre los modos de influir en el desempeño competencial de los procesos de enseñanza y evaluación actuales en la educación superior.

Palabras clave: percepción de desempeño de competencias; factor motivacional en el desempeño de competencias; enseñanza explícita de competencias; evaluación explicita de competencias.

Correspondencia: José Juan Carrión Martínez. Ctra. De Sacramento, s/n, 04120. Almería. E-mail: jcarrion@ual.es

\section{Introduction}

For several decades, a scenario has appeared (De Rider, 2000; Dutton \& Kholi, 1996) wherein the focus on competencies has been widely imposed in higher education (Arranz, Ubierna, Arroyabe, Pérez, \& Fernández de Arroyabe, 2017; Duncan, Bell, \& Atlas, 2017; Eizagirre Sagardia, Altuna Urdin, \& Fernández Fernández, 2017; Herrmann, Gerlach, \& Seelig, 2015). This is the context in which the European Higher Education Area exists (Declaration of Bologna, 1999) and in which the Tuning Project (González \& Wagenaar, 2003) can be considered the referent in curricular transformations of the university educational systems grouped around the aforementioned Declaration.

We can affirm that the competency approach of university curricula has become universal (Bologna Declaration, 1999; Díaz-Barriga, 2011; Einarsdottir, Purola, Johansson, Broström, \& Emilson, 2015; Khan \& Law, 2015; Montoya, 2009; Vegas \& Petrow, 2007; Yao \& Guo, 2018). This strategic approach has been designed and disseminated continuously and in succession at different rates and speeds by means of the curricular designs of university studies around the world. The following studies are representative of the diversity of the dissemination and impact of the aforementioned focus on distant and different university systems. (Alexander, Karvonen, Ulrich, Davis, \& Wade, 2012; González Brito, 2007; Icarte \& Labate, 2016; Klein-Collins, 2012; Maldonado García, 2010; Muñoz \& Sobrero, 2018; Pfeiffer et al., 2013; Thompson, Chmielewski, Gaines, Hrycyna, \& LaCourse, 2013; ur Rehman, 2016; Zabalza Beraza, 2012).

In the case of Spain, the approach, in addition to being a strategic commitment as indicated by Calvo-Bernardino (2009), is also a commitment towards competitiveness, employability and comparability, which can aid towards the building of mutual understanding and a more sharing society (García Manjón \& Pérez López, 2008; García-San Pedro, 2009). It is also considered to be a way of teaching innovation, which is itself considered to be an important challenge for the entire education system (Pallisera, Fullana Noell, Planas Lladó, \& Valle Gómez, 2010). 
The above notwithstanding, authors such as Palomero Pescador \& Torrego Egido (2004), Pérez Cabani, Juando Bosch, \& Argelagos (2014), Robles-Haros \& Estévez-Nenninger (2016), Martínez Gómez (2016) or Zapata Callejas (2015) highlight some relevant shortcomings that still need to be revised, such as teacher training, lack of methodology for practical application, lack of resources or the fact that teaching is dependent on economic or business interests.

\section{Competencies, content and the development of the training process}

Once the consolidated presence of competency-based curricula of university studies has been acknowledged, the presence and development of many studies based on that epistemological framework, particularly in the context of higher education become manifest. The studies focus as much on aspects of its constitutive structure defined around sets of competencies, as it does on the teaching-learning process as a means of focusing on performance and results.

Among these studies we find papers on the taxonomies of competencies, in some cases with special emphasis on transversal and / or generic competencies (Albarrán Villalba, 2018; Alpizar Muní, 2008; Salcines, González-Fernández, Ramírez-García, \& Martínez-Mínguez, 2018). Others place special emphasis on the specific competencies of various degrees (Biesma et al., 2008; Sosa and Silva García, Magaña Martínez, Rodríguez Cebreros; \& Jiménez López, 2018), or on the teaching of these and their associated teaching practices (Buckingham Shum \& Crick, 2016; Cuellar, Muñoz Montenegro, \& Pedraza Hurtado, 2018; Monterroso, Baile, \& Pérez, 2015; Pulham \& Graham, 2018; Robinson, 2018; Sadler, Foulk, \& Friedrichsen, 2017; Villardón-Gallego , 2015; Wiek et al., 2015). Whilst others study their assessment in the context of university curricula (Bergsmann, Schultes, Winter, Schobe, \& Spiel, 2015; Fernandes, Sotolongo, \& Martínez, 2016; San Martín Gutiérrez, Jiménez Torres; \& Sánchez-Beato, 2016; Tejada Fernández \& Rubio Bueno, 2015).

Social work is not excluded from this phenomenon and there are diverse and numerous studies that analyze the curricula of social work studies in various institutional and / or geographical contexts. Among these studies, we can cite, for example, the works of Farias Olavarría \& Rodríguez Romero (2016), Fonseca Mendoza, Amaya López \& Gómez Martínez (2017) or Nurius, Coffey, Fong, Korr, \& McRoy (2017). The above cited studies, along with many others, document the many different and varied analyses of the impact of competency-based learning on social work education at university level.

With reference to the previous contextual framework and its varied research results, we must ask what elements are considered to more relevant when it comes to teaching skills and competencies to students and future social workers. Hence, competencies, which are at the heart of the multiple and extended curricular redesigns in progress and are part of a basically structural element in terms of content, whether they are discussed or not, are, in essence, what we intend to train future graduates of social work. However, the value of each functional element of the curricular process developed for social work education, is relatively unknown.

There are studies that seem to indicate that students perceive the teaching and explicit assessment of the competencies that make up the design of their curriculum to be limited with regards to both 
transversal (Albarrán Villalba, 2018) and specific competencies (Martínez Sánchez, 2009). As a result, a need has emerged to analyze the factors that can best explain the performance of specific competencies as pertains to future professional social workers.

Consequently, it seems necessary to consider whether all these important transformative efforts by university education systems in the teaching of social work have a perceptible projection in the teaching and learning framework, given that it not only affects the substance of the curriculum, but also the procedural elements. That is, they affect the action of teaching and assessment itself, as it is a process of transformation that has not been limited to reformulating what is taught, but also how it is taught and what and how it is assessed.

The aforementioned is an indication of the need to understand if such elements of the complex instructional system, namely, explicit teaching and assessment of specific competencies in the training of future social workers, are being effective in promoting, improving or training in the performance of said specific competencies, or if indeed, other elements of an axiological or extracurricular nature best explain the performance of the specific competencies in undergraduates studying social work. This interest is justified in that we consider it necessary to replace certain descriptive perceptions with more structural analyses that validate the formative model or require a continued review the methodological and evaluative changes as proactive actions in order to improve the performance of those undergoing training.

In summary, it is necessary to analyze if the perceived performance is influenced by the very substance of the values involved in the competencies, and if teaching and evaluation, by themselves lead to improved performances, particularly when there are indicators that can lead us to question the latter, such as those mentioned by Duron \& Giardina (2018), and confirmed by Robinson (2018) who point to the involvement of students in their learning or linking this with field work as being more decisive than strictly pedagogical elements such as the explanation of teaching and / or assessment.

\section{Methodology}

\section{Objective}

To determine the relationship and influence between the perceived performance of the specific competencies by undergraduates studying social work and the actions of teaching and explicit assessment, and to analyze the role of the axiological dimension of this relationship.

\section{Participants}

The sample consisted of 220 subjects, all undergraduate students studying social work. $76.8 \%$ of the sample were women and $23.2 \%$ were men. The students were selected from among various cohorts, depending on their availability, as is frequent and recognized for studies in educational contexts (Hernández Sampieri, 2018; McMillan \& Schumacher, 2012). The gender structure of the sample is considered equivalent with the population structure of social workers. 
With respect to the age variable, considering our study, we chose to group students into two categories, those aged under 25 and those that were aged 25 and over, representing $74.5 \%$ and $25.5 \%$ of the sample, respectively.

\section{Instruments}

The subjective perceptions described below were evaluated using an inventory created specifically for the present study based on the specific competencies proposed for the degree in social work by Vázquez Aguado (2005), which were adopted by Spanish universities, and used in its entirety by the University of Almería (University of Almería, 2010) (See Annex I). Thus, once each of the competencies was stated (e.g., Establishment of professional relations), the participants were asked to assess the following four aspects: (a) the subjective level of attributed importance (i.e., Competency Valuation), (b) the subjective level of their own personal competency (i.e., Competency Performance), (c) the subjective level of explicit education received (i.e., Competency Teaching) and (d) the subjective level of explicit assessment received (i.e., Competency Assessment). The response to the items was made using a Likert scale that ranged from 0 (Very low) to 3 (Very high). In the present study, the internal consistency values of the instrument were $\alpha$ $=0.94$ (Competency Valuation), $\alpha=0.92$ (Competency Performance), $\alpha=0.93$ (Competency Teaching), and $\alpha=0.95$ (Competency Assessment).

\section{Procedure}

The instrument was applied directly in person to the undergraduate classes by the researchers, after attaining prior consent from the University Directorate and of the teachers who were imparting instruction at the time. To this end, permission was granted to occupy an interval of 60 minutes for the administration of the questionnaire. No time limits were set, and paper was used for the response protocols.

No authorization was required from the Bioethics Commission of the University of Almeria (in which the research project that was the origin of this work was approved) since this type of survey does not contain information which could affect the ideological rights or opinions of adults. However, as the questionnaire was administered in paper format and in person, a strict adherence to the Code of Good Practices in Research of the University of Almería (University of Almería, 2011) required that the students receive an explanation of the commitment to confidentiality and the prior attainment of their informed consent in order to respect the voluntary nature of its completion, both before starting the application and during the process of completion and delivery of response in a box enabled for this purpose.

\section{Data Analysis}

First, both missing data patterns and the existence of atypical data (i.e., $z$-score $>4$ ) were examined (Hair, Black, Babin, \& Anderson, 2010). Next, descriptive statistics, bivariate correlations between continuous variables, and both sex age group (i.e., students aged under 25 or those that 
were aged 25 or over) differences in Competency Performance values were obtained and interpreted according to their effect size (i.e., Cohen's $d, 1988$ ). Then, a two-step linear regression analysis predicting Competency Performance was carried out. In this analysis, age group, sex, Competency Valuation, Competency Teaching, and Competency Assessment were introduced in the first step, whereas the interaction terms between these last three variables were introduced in the second step. The independent variables whose possible interaction effects were examined were previously mean-centered. In order to interpret the observed interactions, the regression lines corresponding to those participants with relatively high/low levels (i.e., \pm one standard deviation) of Competency Teaching and Competency Assessment were represented graphically (Aiken, 2003). In order to minimize the effects of a possible lack of normality in the distribution of the data, a non-parametric bootstrapping technique of 5,000 resamples was applied in the regression analysis (Hayes, 2009).

\section{Results}

The percentage of missing data for the categorical variables (i.e., items) was $0.51 \%$, so they were replaced by the mode value (Rini et al., 2011). The descriptive statistics and correlations between the study variables are shown in Table 1. Correlations of medium magnitude were observed between, on the one hand, "Competency Valuation", "Competency Teaching", and "Competency Assessment" and, on the other, "Competency Performance". Additionally, differences in Competency Performance of small magnitude favoring both women $(d=0.34)$ and those under $25(d$ $=0.27$ ) were found.

Table 1. Descriptive Statistics and Correlational Analysis

\begin{tabular}{|c|c|c|c|c|c|c|c|c|c|}
\hline & $\begin{array}{c}\text { Possible } \\
\text { Range }\end{array}$ & $M$ & $S D$ & Skewness & Kurtosis & 1 & 2 & 3 & 4 \\
\hline $\begin{array}{l}\text { 1. Competency } \\
\text { Valuation }\end{array}$ & $0-3$ & 2.25 & 0.56 & -0.72 & 0.47 & - & & & \\
\hline $\begin{array}{l}\text { 2. Competency } \\
\text { Teaching }\end{array}$ & $0-3$ & 1.38 & 0.54 & -0.19 & -0.36 & $-0.15^{*}$ & - & & \\
\hline $\begin{array}{l}\text { 3. Competency } \\
\text { Assessment }\end{array}$ & $0-3$ & 1.28 & 0.65 & 0.06 & -0.80 & $-0.16^{*}$ & $0.81 * * *$ & - & \\
\hline $\begin{array}{l}\text { 4. Competency } \\
\text { Performance }\end{array}$ & $0-3$ & 1.78 & 0.49 & -0.12 & 0.38 & $0.30 *$ & $0.42 * * *$ & $0.29 *$ & - \\
\hline
\end{tabular}

$* p<.05 ; * * p<.01 ; * * * p<.001$

The results of the regression analysis (see Table 2) revealed that, once the effects of both age group and sex were controlled, Competency Valuation and Competency Teaching were positively and significantly related to Competency Performance, explaining a 35\% of its variance. The interaction terms introduced in the second step were related to with Competency Performance both negatively (in the case of the interaction between Competency Teaching and Competency Valuation) and positively (in the case of the interaction between Competency Assessment and 
Competency Valuation). Despite the similar magnitude of these two relationships, the latter did not reach the established statistical significance level. The inclusion of the interaction terms explained an additional 3\% of the variance in Competence Performance.

Table 2. Result of Regression/Moderation Analysis Predicting Competency Performance

\begin{tabular}{|c|c|c|c|c|c|c|c|c|}
\hline & & & & $\boldsymbol{B}$ & & & & \\
\hline & $\beta$ & & & $95 \%$ & & & $R^{2}(p)$ & $D R^{2}$ \\
\hline & & Estimate & Lower & Upper & $S E$ & $p$ & & \\
\hline Stage 1 & & & & & & & $.35(<.001)$ & - \\
\hline Aged over 25 & -.18 & -0.20 & -0.32 & -0.08 & 0.06 & .002 & & \\
\hline Men & -.07 & -0.07 & -0.20 & 0.05 & 0.06 & .220 & & \\
\hline Competency Valuation & .39 & 0.33 & 0.22 & 0.46 & 0.06 & $<.001$ & & \\
\hline Competency Teaching & .55 & 0.50 & 0.26 & 0.68 & 0.12 & $<.001$ & & \\
\hline Competency Assessment & -.10 & -0.07 & -0.25 & 0.15 & 0.09 & .404 & & \\
\hline Stage 2 & & & & & & & $.38(<.001)$ & .03 \\
\hline Aged over 25 & -.17 & -0.19 & -0.31 & -0.07 & 0.06 & .004 & & \\
\hline Men & -.06 & -0.07 & -0.18 & 0.06 & 0.06 & .262 & & \\
\hline Competency Valuation & .31 & 0.27 & 0.04 & 0.53 & 0.10 & .010 & & \\
\hline Competency Teaching & .57 & 0.51 & 0.27 & 0.67 & 0.13 & $<.001$ & & \\
\hline Competency Assessment & -.05 & -0.04 & -0.30 & 0.29 & 0.13 & .759 & & \\
\hline $\begin{array}{l}\text { Competency Teaching x } \\
\text { Competency Valuation }\end{array}$ & -.34 & -0.27 & -0.52 & 0.07 & 0.15 & .017 & & \\
\hline $\begin{array}{l}\text { Competency Teaching x } \\
\text { Competency Assessment }\end{array}$ & .07 & 0.03 & -0.18 & 0.24 & 0.11 & .788 & & \\
\hline $\begin{array}{l}\text { Competency Assessment } \\
\text { x Competency Valuation }\end{array}$ & .26 & 0.18 & -0.06 & 0.39 & 0.12 & .055 & & \\
\hline
\end{tabular}

Note. $\beta=$ Standardized Regression Coefficients; $B=$ Non-Standardized Regression Coefficients; $\mathrm{CI}=$ Confidence Interval; $S E=$ Standard Error. Results were obtained by employing a 5,000 resamples bootstrapping technique.

\section{Discussion and Conclusions}

The results suggest that the subjective assessment of the competencies by undergraduate students of social work could affect the relationship between the perception of teaching and evaluation of the competencies and the subjective level of the competency itself. Specifically, in such a way that (a) the positive relationship between Competency Teaching and Competency Performance would decrease in the presence of higher levels of Competency Valuation and (b) the negative relationship between Competency Assessment and Competency Performance which would be dampened in the presence of higher levels of Competence Valuation (Figure 1). 

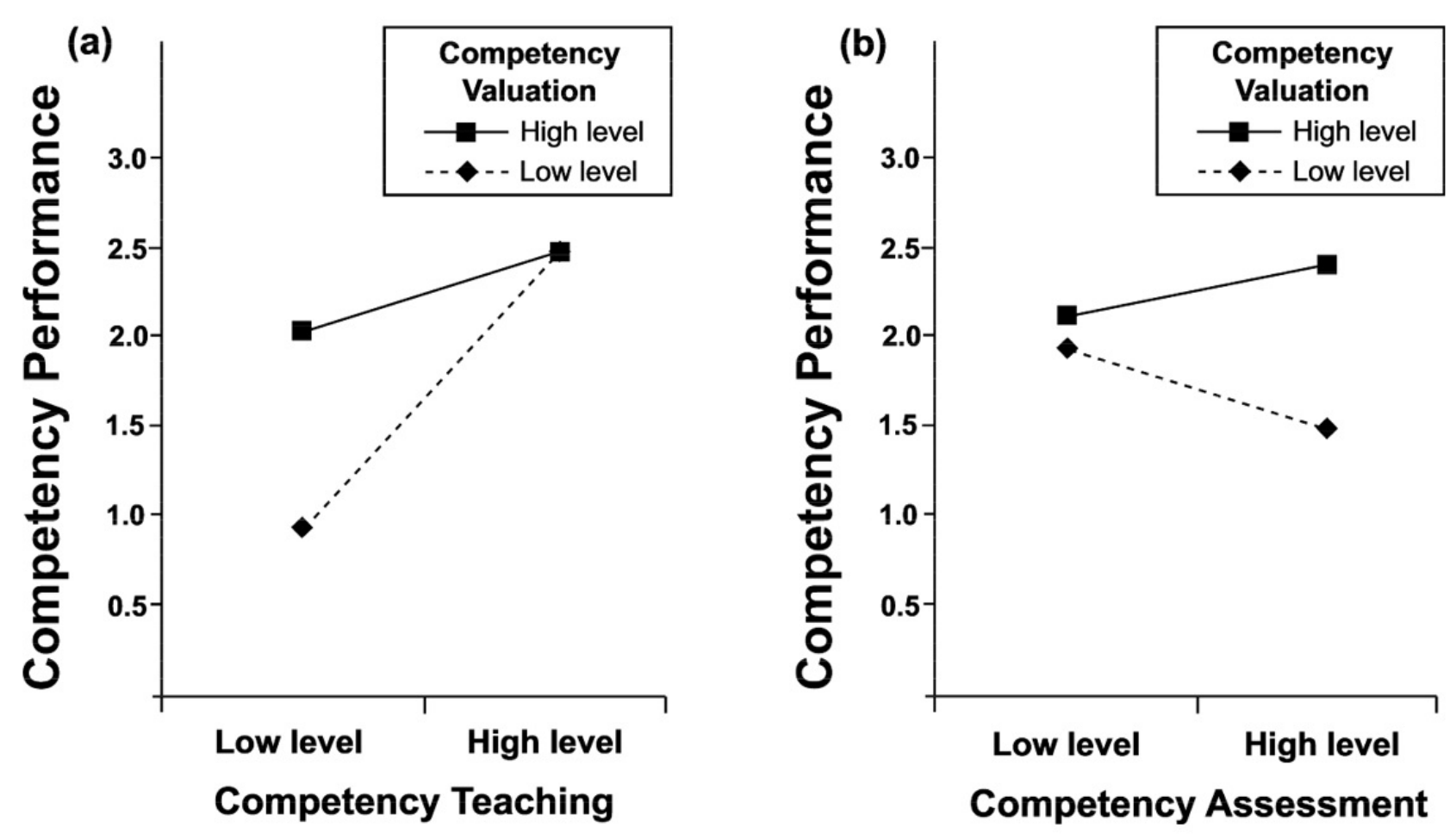

Figure 1. Effects of the interactions between (a) Competency Teaching and Competency Valuation, and (b) Competency Assessment and Competency Valuation on Competency Performance. High/low levels correspond to one standard deviation above/below the mean levels of the variables.

As Lassnigg (2017) points out, there are scarcely any studies that prove that competency-based education is a positive model and even fewer that confirm that there is evidence of a relationship between the performance of those competencies and the training models themselves. In fact, we have not found a single specific study on university level training in competencies in the context of social work education. The above notwithstanding, we did find works such as those by Doel, Shardlow, \& Sawdon, (2017) that provide guidelines on how to develop competencies in the teaching of social work, or those by Navrátilová \& Navrátil (2016) that conduct a systematic review and address the issue of how discourses on social work influence pedagogical practices, or the article by Braun \& Mishra (2016) that focuses on the evaluation of competencies in the general field of higher education. We likewise did not find any reference to the axiological dimension and the curricular pedagogical dimensions related with performance.

From this point of view, the results lead us to an inescapable reflection on the validity of pedagogical practices that promote the self-perceived performance of the specific competencies of social work by undergraduate students, future professional beneficiaries of those capacities, since, while the influence of teaching is positive, it is mediated by the value attributed to competencies. This leads us, on the one hand, to point out that the value system is possibly more decisive than the proactive action of the training system itself, as it is even more relevant in the assessment component than in the teaching of that training system. As a consequence, the works of Duron and Giardina (2018) and Robinson (2018) take on greater significance in that they indicated that teaching exerts greater influence when teaching methodologies related to professional field work 
were adopted, an interpretation which is compatible with our results. That is to say, that if the teaching is developed to include values such as those that appear in professional field work, then performance improves. This seems to us to be of great importance when it comes to reviewing how we teach social work, because instead of insisting or reiterating didactic technology when defining teaching learning activities and their assessment, the training model must be opened up to include implicative formats where the appropriation of competencies is done in contexts mediated by immersion in field work, pre-professional practices, problem solving, the inclusion of real case studies and other formats where values are the focus of competency performance. If we draw on training models with a high commitment in values, we are likely to attain better competitive performance in future social workers.

\section{References}

Albarrán Villalba, M. J. (2018). Estudio sobre la implantación y enseñanza de las competencias transversales en las titulaciones de grado en la universidad de Almería. (Doctoral Thesis) University of Almería, Spain.

Aiken, L. R. (2003). Tests psicológicos y evaluación. México D.F., México: Pearson Educación. Alexander, A., Karvonen, M., Ulrich, J., Davis, T., \& Wade, A. (2012). Community college faculty competencies. Community College Journal of Research and Practice, 36(11), 849-862.

Alpizar Muní, J. L. (2008). ¿Profesionales competitivos o competentes? II. Tipología de competencias. Pedagogía Universitaria, 13(4), 1-14.

Arranz, N., Ubierna, F., Arroyabe, M. F., Pérez, C., \& Fdez. de Arroyabe, J. C. (2017). The effect of curricular and extracurricular activities on university students' entrepreneurial intention and competences. Studies in Higher Education, 42(11), 1979-2008.

Bergsmann, E., Schultes, M. T., Winter, P., Schober, B., \& Spiel, C. (2015). Evaluation of competence-based teaching in higher education: From theory to practice. Evaluation and program planning, 52, 1-9.

Biesma, R. G., Pavlova, M., Vaatstra, R., van Merode, G. G., Czabanowska, K., Smith, T. \& Groot, W. (2008). Generic versus specific competencies of entry-level public health graduates: employers' perceptions in Poland, the UK, and the Netherlands. Advances in Health Sciences Education, 13(3), 325-343.

Bracy, W. (2018). Building a Competency-Based Curriculum in Social Work Education. Journal of Teaching in Social Work, 38(1), 1-17.

Braun, E., \& Mishra, S. (2016). Methods for assessing competences in higher education: A comparative review. In J. Huisman, \& M. Tight (Eds.), Theory and method in higher education research (pp. 47-68). Bingley, UK: Emerald Group Publishing Limited.

Buckingham Shum, S., \& Crick, R. D. (2016). Learning Analytics for 21st Century Competencies. Journal of Learning Analytics, 3(2), 6-21.

Calvo-Bernardino, A. (2009). La estrategia de las universidades frente al Espacio Europeo de Educación Superior/University Strategy and the European Higher Education Area. Revista Complutense de Educación, 20(2), 319-342.

Cohen, J. (1988). Statistical power analysis for the behavioral sciences. Hillsdale, New Jersey: Lawrence Erlbaum. 
Cuellar, L. A., Muñoz Montenegro, E., \& Pedraza Hurtado, A. Z. (2018). Estilos de enseñanza $\mathrm{y}$ desarrollo de competencias investigativas en educación superior. Inclusión \& Desarrollo, 5(2), 83-100.

Ridder, G. D. (2000). Les professions sociales en France: Du modèle de la qualification au modèle de la compétence? European Journal of Social Work, 3(2), 139-150.

Declaración de Bolonia (1999). Declaración conjunta de los Ministros Europeos de Educación. Bolonia. Accessed 19th of June 1999. http://www.educacion.gob. es/boloniaensecundaria/ img/Declaracion_Bolonia.pdf (Accessed 29th of January 2018).

Díaz-Barriga, A. (2011). Competencias en educación. Corrientes de pensamiento e implicaciones para el currículo y el trabajo en el aula. Revista Iberoamericana de Educación Superior, 2(5). 3-24.

Doel, M., Shardlow, S., \& Sawdon, D. (2017). Teaching social work practice: A programme of exercises and activities towards the practice teaching award. London, UK: Routledge.

Duncan, C., Bell, T., \& Atlas, J. (2017, January). What do the teachers think?: introducing computational thinking in the primary school curriculum. In Proceedings of the Nineteenth Australasian Computing Education Conference (pp. 65-74).

Duron, J.F, \& Giardina, T.D. (2018) Teaching philosophies and practices in social work education: do the core competencies influence our consciousness? Social Work Education, 37(5), 603616. doi: 10.1080/02615479.2018.1450371

Dutton, J., \& Kohli, R. (1996). The core skills of social work. Social Work Competencies London, UK: Sage Publications.

Einarsdottir, J., Purola, A. M., Johansson, E. M., Broström, S., \& Emilson, A. (2015). Democracy, caring and competence: Values perspectives in ECEC curricula in the Nordic countries. International Journal of Early Years Education, 23(1), 97-114.

Eizagirre Sagardia, A., Altuna Urdin, J., \& Fernández, I. (2017). Prácticas de éxito en el desarrollo de competencias transversales en centros de Formación Profesional del País Vasco. Revista Española de Pedagogía, 75 (297), 293-308.

Farias Olavarría, F., \& Rodríguez Romero, O. (2016). Evaluación de las competencias genéricas de los/as trabajadores sociales en el ejercicio directo de la profesión. Cuadernos de Trabajo Social, 6, 35-56.

Fernandes, D. J., Sotolongo, M., \& Martínez, C. C. (2016). La evaluación del desempeño por competencias: percepciones de docentes y estudiantes en la educación superior. Formación universitaria, 9(5), 15-24.

Fonseca Mendoza, A. L., Amaya López, N. T. A, \& Gómez Martínez, L. A. (2017). La formación en competencias para el programa de Trabajo Social en la Universidad de la Guajira: un camino abierto a la diversidad y la educación. Praxis, 13(1), 47-55.

García Manjón, J. V., \& Pérez López, M. C. 2008). Espacio Europeo de Educación Superior: competencias profesionales y empleabilidad. Revista iberoamericana de educación, 46(9), $1-12$.

García-San Pedro, M.J. (2009). El concepto de competencias y su adopción en el contexto universitario. Revista Alternativas. Cuadernos de Trabajo Social, 16, 11-28,

González Brito, A. I. (2007). Formación inicial basada en competencias. Horizontes Educacionales, 12(2), 37-41. 
González, J. \& Wagenaar, R. (2003). Tuning Educacional. Bilbao: Universidad de Deusto.

Hair, J. F., Black, W. C., Babin, B. J., \& Anderson, R. E. (2010). Multivariate data analysis: A global perspective. Upple Saddle River, NJ: Prentice-Hall.

Hayes, A. F. (2009). Beyond Baron and Kenny: Statistical mediation analysis in the new millennium. Communication Monographs, 76(4), 408-420. doi:10.1080/03637750903310360

Hernández Sampieri, R. (2018). Metodología de la investigación: las rutas cuantitativa, cualitativa y mixta. México D.F., México: McGraw Hill.

Herrmann, C., Gerlach, E., \& Seelig, H. (2015). Development and validation of a test instrument for the assessment of basic motor competencies in primary school. Measurement in Physical Education and Exercise Science, 19(2), 80-90.

Icarte, G. A., \& Labate, H. A. (2016). Metodología para la revisión y actualización de un diseño curricular de una carrera universitaria incorporando conceptos de aprendizaje basado en competencias. Formación universitaria, 9(2), 03-16.

Khan, M. A., \& Law, L. S. (2015). An Integrative Approach to Curriculum Development in Higher Education in the USA: A Theoretical Framework. International Education Studies, 8(3), 66-76.

Klein-Collins, R. (2012). Competency-Based Degree Programs in the US: Postsecondary Credentials for Measurable Student Learning and Performance. Chicago, USA: Council for Adult and Experiential Learning (CAEL).

Lassnigg, L. (2017). Competence-based education and educational effectiveness. In M. Mulder, Competence-based Vocational and Professional Education (pp. 667-693). Wageningen, The Netherlands: Springer.

Maldonado García, M. Á. (2010). Currículo con enfoque de competencias. Bogotá, Colombia: Ecoe ediciones.

Martínez Gómez, F. (2016). La formación universitaria versus las necesidades empresariales en el marco del EEES. La cuestión universitaria, 5, 180-190.

McMillan, J. H. \& Schumacher, S. (2012). Investigación Educativa: una introducción conceptual. Madrid, Spain: Pearson Educación.

Martínez Sánchez, A. (2009). Las competencias específicas en el título de Grado de Educación Infantil (Doctoral Thesis), University of Granada, Granada, Spain.

Monterroso, E., Baile, J. I., \& Pérez, S. (2015). Innovative educational experiences in the university teaching of law and psychology using virtual environments. In M. Gisbert and M. Bullen (Eds.), Teaching and learning in digital worlds. Strategies and issues in higher education (pp.193-200), Tarragona, Spain: Universidad Rovira i Virgili.

Montoya, J. (2009). The Current State of Legal Education Reform in Latin America: A Critical Appraisal. J. Legal Education, 59, 545.

Muñoz, A. L., \& Sobrero, V. (2018). Proyecto Tuning en Chile: análisis de procesos de internacionalización de la educación superior. Calidad en la Educación, 24, 249-271.

Navrátilová, J., \& Navrátil, P. (2016). Educational Discourses in Social Work. Sociální pedagogika. Social Education, 4(1), 38-56.

Nurius, P. S., Coffey, D. S., Fong, R., Korr, W. S., \& McRoy, R. (2017). Preparing professional degree students to tackle grand challenges: A framework for aligning social work curricula. Journal of the Society for Social Work and Research, 8(1), 99-118. 
Pallisera, M., Fullana Noell, J., Planas Lladó, A., \& Valle Gómez, A. D. (2010). La adaptación al Espacio Europeo de Educación Superior en España: los cambios/retos que implica la enseñanza basada en competencias y orientaciones para responder a ellos. Revista Iberoamericana de Educación, 52(4), 1-13.

Palomero Pescador, J.E. y Torrego Egido, L. (2004). Europa y calidad docente. ¿Convergencia o reforma educativa? Revista Interuniversitaria de Formación del Profesorado, 18(3), 23-40.

Pérez Cabani, M.L., Juando Bosch, J., \& Argelagos, E. (2014). Testing a model of Competencebased Teaching. 3rd Cyprus International Conference on Educational Research (CYICER 2014). Procedia Social and Behavioral Sciences. 143, 31-34. doi: 10.1016/j. sbspro.2014.07.352

Pfeiffer, J., Beschta, J., Hohl, S., Gloyd, S., Hagopian, A., \& Wasserheit, J. (2013). Competencybased curricula to transform global health: redesign with the end in mind. Academic Medicine, 88(1), 131-136.

Pulham, E., \& Graham, C. R. (2018). Comparing K-12 online and blended teaching competencies: A literature review. Distance Education, 39(3), 411-432.

Rini, C., Jandorf, L., Goldsmith, R. E., Manne, S. L., Harpaz, N., \& Itzkowitz, S. H. (2011). Interpersonal influences on patients' surgical decision making: The role of close others. Journal of Behavioral Medicine, 34(5), 396-407. doi:10.1007/s10865-011-9323-y

Robinson, E.L. (2018) Immersion Learning in Social Work Education: A Pedagogical Tool for Enriching Knowledge and Practice Skills among BSW Students, Journal of Teaching in Social Work, 38(5), 536-550. doi:10.1080/08841233.2018.1516712

Robles-Haros, B. I., \& Estévez-Nenninger, E. H. (2016). Enfoque por competencias: Problemáticas didácticas que enfrentan el profesorado Revista Electrónica Educare, 20 (1), 1-12.

Sadler, T. D., Foulk, J. A., \& Friedrichsen, P. J. (2017). Evolution of a model for socio-scientific issue teaching and learning. International Journal of Education in Mathematics, Science and Technology, 5(2), 75-87.

Salcines, I., González-Fernández, N., Ramírez-García, A., \& Martínez-Mínguez, L. (2018). Validación de la escala de autopercepción de competencias transversales y profesionales de estudiantes de educación superior. Profesorado, Revista de Currículum y Formación del Profesorado, 22(3), 31-51.

San Martín Gutiérrez, S., Jiménez Torres, N., \& Sánchez-Beato, E. J. (2016). La evaluación del alumnado universitario en el Espacio Europeo de Educación Superior. Aula Abierta, 44(1), 7-14.

Sosa y Silva García, Y., Magaña Martínez, M., Rodríguez Cebreros, J., \& Jiménez López, M. (2018). The Quality of Postgraduate in Law in Mexico: Case UABC. US-China. Law. Review., 15(2), 115-120.

Tejada Fernández, J., \& Rubio Bueno, C. (2015). Evaluación de competencias profesionales en educación superior: retos e implicaciones. Educación XX1, 19(1), 17-38. doi:10.5944/ educXX1.12175

Thompson, K. V., Chmielewski, J., Gaines, M. S., Hrycyna, C. A., \& LaCourse, W. R. (2013). Competency-based reforms of the undergraduate biology curriculum: Integrating the physical and biological sciences. CBE—Life Sciences Education, 12(2), 162-169. 
Universidad de Almería (2010). Grado en Trabajo Social. Plan de Estudios. http:/cms.ual.es/ UAL/estudios/grados/plandeestudios/GRADO6810 (Accessed 29th of January 2018).

Universidad de Almería (2011). Código de Buenas Prácticas en Investigación. http://cms.ual. es/idc/groups/public/@vic/@vinvestigacion/documents/documento/vinvest-cbpi_2011.pdf (Accessed 29th of January 2018).

Rehman, S. (2016). Developing new competencies among LIS professionals: Challenges for educators. Pakistan. Journal of Information Management \& Libraries (PJIM\&L), 9(1), 67-81.

Vázquez Aguado, O. (coord.). (2005). Libro Blanco. Título de Grado en Trabajo Social. Madrid: Agencia Nacional de Evaluación de la Calidad y Acreditación.

Vegas, E., \& Petrow, J. (2007). Raising student learning in Latin America: The challenge for the 21st century. The World Bank.

Villardón-Gallego, L. (2015). Competencias Genéricas en Educación Superior: metodologías especificas para su desarrollo. Madrid, España: Narcea Ediciones.

Wiek, A., Bernstein, M., Foley, R., Cohen, M., Forrest, N., Kuzdas, C., ... \& Withycombe Keeler, L. (2015). Operationalising competencies in higher education for sustainable development. In M. Barth, G., Michelsen, M. Rieckmann, \& I. Thomas (Eds.), Handbook of Higher Education for Sustainable Development (pp. 241-260). London, UK: Routledge.

Yao, J. X., \& Guo, Y. Y. (2018). Core competences and scientific literacy: the recent reform of the school science curriculum in China. International Journal of Science Education, 40(15), 1913-1933.

Zabalza Beraza, M. A (2012). Articulación y rediseño curricular: el eterno desafío institucional. REDU: Revista de Docencia Universitaria, 10(3), 17-48.

Zapata Callejas, J. (2015). El modelo y enfoque de formación por competencias en la Educación Superior: apuntes sobre sus fortalezas y debilidades. Revista Academia y Virtualidad, 8(2), 24-33. 


\section{Annex I: Specific competencies of the Undergraduate Degree in Social Work (From University of Almeria, 2010)}

1. Establish professional relationships in order to identify the most appropriate form of intervention.

2. Intervene with individuals, families, groups, organizations and communities to help them make informed decisions about their needs, circumstances, risks, preferred options and resources.

3. Assess the needs and possible options to guide an intervention strategy.

4. Respond to crisis situations by assessing the urgency of the situations, planning and developing actions to address them and reviewing their results.

5. Interact with people, families, groups, organizations and communities to achieve changes, to promote their development and to improve their living conditions through the use of Social Work methods and models, regularly monitoring changes that may occur in order to prepare for the completion of the intervention.

6. Prepare, produce, implement and evaluate intervention plans with the client system and professional colleagues by negotiating the provision of services that must be used and reviewing the effectiveness of the intervention plans with the people involved in order to adapt them to the needs and changing circumstances.

7. Support the development of networks to meet the needs and work in favor of the planned results by examining with the people the support networks that they can access and develop.

8. Promote the growth, development and independence of people by identifying opportunities to form and create groups, using group programming and dynamics for individual growth and the strengthening of interpersonal relationship skills.

9. Work with the behaviors that represent a risk for the client system by identifying and evaluating the situations and circumstances that shape said behavior and developing strategies to modify them.

10. Analyze and systematize the information provided daily as a support to review and improve professional strategies that must respond to emerging social situations.

11. Use mediation as an intervention strategy aimed at alternative conflict resolution.

12. Design, implement and evaluate social intervention projects.

13. Defend individuals, families, groups, organizations and communities and act on their behalf should the situation require it.

14. Prepare and participate in decision-making meetings in order to better defend the interests of individuals, families, groups, organizations and communities.

15. Establish and act for the resolution of situations of risk prior identification and definition of the nature of the same.

16. Establish, minimize and manage risk to oneself and colleagues through the planning, review and monitoring of actions to limit stress and risk.

17. Manage and be responsible for their own work by assigning priorities, complying with professional obligations and evaluating the effectiveness of the work program itself.

18. Contribute to the administration of resources and services by collaborating with the procedures involved in obtaining them, supervising their effectiveness and ensuring their quality.

19. Manage, present and share stories and social reports keeping them complete, faithful, accessible and updated as a guarantee for decision making and professional valuations. 
20. Work effectively within interdisciplinary and "multiorganizational" systems, networks and teams with the purpose of collaborating in the establishment of their purposes, objectives and duration, also contributing constructively to the potential of existing disagreements.

21. Participate in the management and management of social welfare entities.

22. Investigate, analyze, evaluate and use current knowledge of the best practices of Social Work to review and update own knowledge about the frameworks.

23. Work within agreed standards for the exercise of Social Work and ensure their own professional development using professional assertiveness to justify their own decisions, reflecting critically on them and using supervision as a means of responding to professional development needs.

24. Manage conflicts, dilemmas and complex ethical problems by identifying them, designing strategies for overcoming and reflecting on their results.

25. Contribute to the promotion of the best practices of Social Work by participating in the development and analysis of the policies that are implemented.

26. Investigate, analyze, evaluate and use current knowledge of the best practices of Social Work to review and update their own knowledge about the frameworks.

27. Work within agreed standards for the exercise of Social Work and ensure their own professional development using professional assertiveness to justify their own decisions, reflecting critically on them and using supervision as a means of responding to professional development needs.

28. Manage conflicts, dilemmas and complex ethical problems by identifying them, designing strategies for overcoming and reflecting on their results.

29. Contribute to the promotion of the best practices of Social Work by participating in the development and analysis of the policies that are implemented. 